Wireless Telegraph Company, Ltd. ; in 1927 he was appointed managing director and general manager of the Societa Italiana Radio Marittima, the posts which he held until his retirement.

\section{Mr. James Wright}

Mr. JAmes WrIght, who died suddenly at his Edinburgh home on January 28, was born in Kirkcaldy, Fife, and educated locally. His father, besides being a keen amateur astronomer with an observatory in his garden, was interested in science generally and gave intelligent encouragement to his son's geological interests. As a young man, Wright, with Robert Dunlop of Dunfermline, John Smith of Dalry and J. L. Begg of Glasgow, joined a group of amateur geologists who used to rise in the small hours to follow their hobby before going to work, and the splendid foreshore exposures of carboniferous rocks in Fife led him to study the Crinoidea. He was encouraged by the late Dr. F. A. Bather, and his first paper was published by the Edinburgh Geological
Society in 1912. He had in all more than thirty papers to his name, the most considerable being a review of the Scottish carboniferous Crinoidea (Trans. Roy. Soc. Edin., 1939). His monograph of the British Carboniferous Crinoidea, published by the Palæontographical Society with 83 plates, was nearly completed at the time of his death.

With opportunities limited by a full-time business career, Wright made himself a world authority in his field, respected by professional workers in all countries. His collection, which is bequeathed to the Royal Scottish Museum, far exceeds in quality all others of similar scope, not least because of his exquisite skill as a preparator of fossils in intractable matrices. He was honoured by the Geological Societies of London (Wollaston Fund, 1928 ; Worth Award, 1956) and Edinburgh (Clough Medal, 194546) and by the Royal Society of Edinburgh (Neill Prize, 1939). He will be missed not only as the only British worker in his field, but also as a wise, humorous and generous host and friend.

R. V. Melville

\title{
NEWS and VIEWS
}

\section{Technology}

THe urgent demands of the national economy for technologists in great numbers and of the highest calibre has placed the reform and expansion of scientific and technological education at all levels from school to university among the most pressing and vital issues of domestic policy in Britain to day. That the educational system has for so long occupied the attention of successive Governments and occasioned the deliberations of numerous committees of inquiry, and the great volume of debate in the Press and other organs of public opinion, testifies both to the gravity of the situation and the fundamental nature of the measures called for. No facile solution to the complex of problems presented by the national shortage of technologists is going to be found, and continual cross-fertilization of ideas between industry and the world of education will be required if an adequate rate of progress is to be maintained. It is very encouraging and timely, therefore, that Technology, a new monthly review of training and education for industry published by The Times (pp. 40 ; 1s. monthly), should appear at this juncture. The leading article in the first issue states that "one of the chief aims of The Times, in publishing Technology, is to provide a platform from which industrialists may declare their needs to the public, to Ministers, and to university professors, technical college heads and schoolmasters and mistresses. In this way, Technology will seek to make plain what industry wants from the educational system and where it is dissatisfied. But," the leader continues, "science is a sovereign state, and teaching is an art, and the education of the minds and characters of young people must be left to those whose skill it is. Technology offers an equal platform to the teacher".

The first issue of Technology, which appeared on March 4, includes a number of incisive and authoritative articles by eminent industrialists, technologists and teachers. Sir Frederick Handley Page and Dr. Willis Jackson discuss education and training for careers in the aircraft and electrical engineering industries respectively, and $\mathrm{Mr}$. Hugh A. Warren describes the French system of centres d'apprentissage. An article by Prof. P. Sargant Florence examines the question of education for management, and Dr. D. J. Urquhart reviews the problems arising in the provision of libraries for technical colleges. There are articles on the use of computing machines in planning for the petroleum industry by D. A. Glen, and on liquid-metal pumps in the nuclear power industry by Prof. G. H. Rawcliffe. There are items of news and comment, including reviews of the work and organization of six of the designated Colleges of Advanced Technology, of the shortage of women technologists and of current technical developments in America. The first issue contains a fully fledged column of Letters to the Editor, reviews of books, plays, films and television. An admirably informal and lucid style is maintained throughout. Even in these days, when the proliferation of journals offers a severe tax on the time of any reader who endeavours to remain well informed on matters of public policy, the publication of Technology will be very widely welcomed as the answer to a genuine need in the present situation. One may look forward to important contributions in the definition of problems and the formulation of solutions from this new review.

\section{Royal Society of Edinburgh : Prize Awards}

THE Council of the Royal Society of Edinburgh has made the following prize awards: Gunning Victoria Jubilee Prize for the period 1952-56 to Dr. H. W. Melville, for his distinguished contributions to reaction kinetics and the physics and chemistry of high polymers; Makdougall-Brisbane Prize (1954-56) to Prof. C. M. Yonge, for his paper in the Proceedings during the period of award and in recognition of his many valuable contributions to marine zoology; James Scott Prize (1957), to Dr. C. D. Broad for a lecture which will be given on November 11, 1957, on "Some Remarks on Change, Continuity, and Discontinuity". The Bruce Preller Lecture (1957) is to 